九州大学学術情報リポジトリ

Kyushu University Institutional Repository

\title{
Nitrogen Management in Rice-Wheat Alternating Cropping System and Wheat Genotype Identification Preferable to Surface Seeding Condition
}

Rahman, M. Ataur

Wheat Research Centre, Bangladesh Agricultural Research Institute

Sufian, M. A.

Wheat Research Centre, Bangladesh Agricultural Research Institute

Saifuzzaman, M.

Wheat Testing station, Bangladesh Agricultural Research Institute

Chikushi, Jiro

Biotron Institute, Kyushu University

https://doi.org/10.5109/24442

出版情報: 九州大学大学院農学研究院紀要. 46 (2)，pp. 295-301，2002-02-28. Kyushu University バージョン：

権利関係 : 


\title{
Nitrogen Management in Rice-Wheat Alternating Cropping System and Wheat Genotype Identification Preferable to Surface Seeding Condition
}

\author{
M. Ataur RAHMAN*, M. A. SUfLAN**, M. SAIFUZZAMAN***, \\ and Jiro CHIKUSHI
}

Biotron Institute, Kyushu University, Fukuoka 812-8581, Japan

(Received October 31, 2001 and accepted November 20, 2001)

\begin{abstract}
A field research was conducted at the research farm of Wheat Research Centre, Dinajpur, Bangladesh for the two consecutive years of 1999-2000 and 2000-2001 to find out the appropriate management of nitrogen fertilizer in surface seeded wheat and to identify the wheat genotype preferable to surface seeding in rice - wheat alternative cropping system. The experiment was executed in split-plot design assigning three wheat genotypes namely Kanchan, Protiva and Gourab in main plots and seven different management of nitrogen fertilizer in subplots. Nitrogen content in grain and straw of wheat was determined; root growth was studied at post anthesis stage of the crop. Both the genotype and $\mathrm{N}$ management have created a significant impact on the root length density (RLD), $\mathrm{N}$ uptake, $\mathrm{N}$ use efficiency and grain yield of surface seeded wheat. Three equal split application of $\mathrm{N}$ fertilizer as basal during seeding, top dress at crown root initiation stage ( 20 days after sowing) and at first node stage ( 35 days after sowing) was found best that produced significantly higher grain yield by increasing spikes $\mathrm{m}^{-2}$ and number of grains spike $\mathrm{e}^{-1}$ RLD at the active root zone $(0-15 \mathrm{~cm}), \mathrm{N}$ uptake and nitrogen use efficiency (NUE) of wheat was the highest under the same $\mathrm{N}$ management. Among the wheat genotypes Kanchan produced higher grain yield that was attributed from higher number of spikes $\mathrm{m}^{-2}$ and number of grains spike ${ }^{-1}$. Agronomic NUE, Grain N, total $\mathrm{N}$ uptake and RLD of Kanchan was higher compare to other genotypes.
\end{abstract}

\section{INTRODUCTION}

The national average yield of wheat in Bangladesh is much lower than the achievable yield at the research stations. Late planting of wheat is one of the major causes of the lower yield of wheat in rice-wheat cropping system in Bangladesh (Ahmed and Meisner, 1996). The two of the main causes of late planting of wheat are the late harvest of the previous rice crop and the long time period from rice harvest to wheat seeding in the intensive irrigated rice-wheat cropping system of Bangladesh (Hobbs et al., 1998). Also in some years and locations due to the late rain or flood the post rice harvest soil remains too moist to plough that land for the next wheat crop in time. Under such a condition seeding of wheat in un-ploughed post rice harvested moist soil surface (surface seeded wheat) could be a better option to take the advantages of residual soil moisture and reduce the time period from rice harvest to wheat seeding in rice-wheat cropping system.

\footnotetext{
* Wheat Research Centre, Bangladesh Agricultural Research Institute, Dinajpur-5200, Bangladesh and Corresponding author

** Wheat Research Centre, Bangladesh Agricultural Research Institute, Dinajpur-5200, Bangladesh

*** Wheat Testing station, Bangladesh Agricultural Research Institute, Gazipur 1201, Bangladesh
} 
The practice also saves the cost of tillage and land preparation. Many works on nitrogen application, rate, timing and placement for wheat under conventional tillage had done (Rahman et al. 2000a, Prashad et al., 1987; Malik, 1981; Khan et al., 1990; OrtizMonasterio et al., 1994; Fisher et al., 1993). Razzaque et al. (1980) recommended twothird $\mathrm{N}$ as basal fertilizer and one-third $\mathrm{N}$ as top dressing at crown root initiation (CRI) stage to get higher yield of wheat in Bangladesh. But in case of surface seeding there are no scopes of incorporation of fertilizers into the soil. Thus the basal fertilizer $\mathrm{N}$ with all other fertilizers remains at the surface of the soil in the direct contact of air and sunshine that might lead to greater loss of $\mathrm{N}$ through volatilization. Thus the $\mathrm{N}$ management in surface seeded wheat might be different from that under conventional wheat cropping. Information on $\mathrm{N}$ management for surface seeded wheat is scarce. There may have some differences in yield performance among the wheat genotypes in surface seeding condition. Thus, it is important to know the various advantages in surface seeded wheat. In this paper we investigated the appropriate $\mathrm{N}$ fertilizer application method in surface seeding condition and identified the wheat genotype suitable for surface seeding.

\section{MATERIAL AND METHODS}

The experiment was conducted in two consecutive years of 1999-2000 and 20002001 at Wheat Research Centre, Dinajpur Bangladesh after harvesting the previous transplanted aman rice grown in the same plots. The design of the experiment was split- plot with three replications. Two factors of wheat genotype and $\mathrm{N}$ application method were involved in the experiment. Three wheat genotypes namely Kanchan, Protiva and Gourab were assigned randomly in the main plots. Seven $\mathrm{N}$ treatments were distributed randomly in the sub plots as follows.

$\mathrm{T}_{\mathrm{i}}=$ Application of two-third of $\mathrm{N}$ as basal dressing and the rest one-third as top dressing at CRI stage at $20 \mathrm{DAS}$ (days after sowing)

$\mathrm{T}_{2}=$ Application of $\mathrm{N}$ all at CRI stage (20 DAS) as top dressing

$\mathrm{T}_{3}=$ Application of $\mathrm{N}$ all at 1st node (35 DAS) as top dressing

$\mathrm{T}_{4}=$ Two equal split application of $\mathrm{N}$ as half basal and half as top dressing at CRI stage

$\mathrm{T}_{5}=$ Two equal split application of $\mathrm{N}$ as half basal dressing and half as top dressing at first node stage

$\mathrm{T}_{6}=$ Two equal split application of $\mathrm{N}$ as top dressing at CRI and at first node stage

$\mathrm{T}_{7}=$ Three equal split application of $\mathrm{N}$ as basal dressing, top dressing at CRI and at 1st node stage.

The soil of the experimental field was sandy loam, including poor organic matter and total $\mathrm{N}$ content. Fertilizers of $\mathrm{P}_{2} \mathrm{O}_{5}, \mathrm{~K}_{2} \mathrm{O}$ and $\mathrm{S}$ were applied at the rate of 60,40 , and $20 \mathrm{~kg}$ $\mathrm{ha}^{-1}$ to all the plots as basal fertilizer on the day of sowing seed. A total of $120 \mathrm{~kg} \mathrm{ha}^{-1} \mathrm{~N}$ from urea was applied in each plot but the application methods and timing were different, as mentioned in sub plot treatments. Seeds were sown on the un-ploughed saturated soil surface with keeping lines of $20 \mathrm{~cm}$ space. Seeding rate was $120 \mathrm{~kg} \mathrm{ha}^{-1}$ and the seeding date were 5th December and 18th November for the year 1999-2000 and 2000-2001 respectively. A small amount of irrigation was conducted one day before the sowing to bear good soil water condition for germination. Four times of irrigations were followed at $20 \mathrm{DAS}$, at $35 \mathrm{DAS}$, and at budding and grain filling stage of wheat. Weed in the field was 
removed by spraying herbicide (2-4 D at $17 \mathrm{DAS}$ ) and by picking by hands on $26 \mathrm{DAS}$ in 1 st year and on 28 DAS in 2nd year. The growth analysis of roots was studied once at post anthesis (Zadok's 6.8 to 7.0) stage of wheat. Soil samples were taken vertically up to $15 \mathrm{~cm}$ depth from three spots of individual plots by using a core sampler. The collected soil column with roots were watered in an individual polyethylene bag and kept over night for swelling and loosening of soil. Then they were washed out in tap water over the plastic net tray. The roots were preserved in a refrigerator immediately to keep those fresh during measurement. Total root length was measured using Newman's (1966) grid method modified by Tennant (1975). Root length density (RLD) was calculated by dividing the total root length with the inner volume of the core sampler. On the day of root sampling the plant shoot of the sampling area of individuals were collected and oven dried to measure root-shoot ratio. At maturity (120 DAS) the crop was harvested plot wise (avoiding the borders) for measuring grain yield at air dried (approx. 12\%) moisture condition. Grain and straw samples from each treatment were also processed for $\mathrm{N}$ determination. Total $\mathrm{N}$ concentration in plant samples was determined by micro Kjeldahl method following $\mathrm{H}_{2} \mathrm{SO}_{4}$ digestion and distillation. Nitrate uptake was estimated by multiplying oven dry weight of the sample with $\mathrm{N}$ content in respective sample. Nitrogen use efficiency (NUE) was calculated as the ratio of grain yield to the total $\mathrm{N}$ uptake by the plants. All data including yield and yield components were subjected to statistical analysis and the means were tested by Duncan's Multiple Range Test at 5\% level of significance.

\section{RESULTS AND DISCUSSION}

\section{Root parameters}

Root parameters, especially the root-shoot ratio and root length density (RLD) are considered as two of the important characters of plant, which are usually changed according to a stressed environment. Root weight, shoot weight, root to shoot ratio and RLD at the active root zone of wheat $(0-15 \mathrm{~cm})$ at post anthesis stage was influenced differently by the genotypes (Table 1a). RLD was the highest $\left(0.62 \mathrm{~mm} \mathrm{~cm}^{-3}\right)$ in Kanchan followed by Protiva and Gourab. The higher RLD of Kanchan indicated the greater proliferation of roots that might contribute to higher nutrient and moisture extraction by the plant, which finally resulted in higher yield (Table $3 \mathrm{a}$ ). There was no varietal

Table 1a. Root-shoot ratio and root length density at the active root growing zone $(0-15 \mathrm{~cm})$ of wheat genotypes under surface seeding condition in 2000-2001

\begin{tabular}{lcccc}
\hline Genotype & $\begin{array}{c}\text { Root weight } \\
\text { mg }\end{array}$ & $\begin{array}{c}\text { Shoot wt. } \\
\mathrm{g}\end{array}$ & $\begin{array}{c}\text { Root:Shoot } \\
\mathrm{mg} \mathrm{g}^{-1}\end{array}$ & $\begin{array}{c}\text { RLD } \\
\mathrm{cm} \mathrm{cm}^{-3}\end{array}$ \\
\hline Kanchan & 1371 & $38.0 \mathrm{a}$ & 36.1 & $0.62 \mathrm{a}$ \\
Protiva & 1256 & $36.0 \mathrm{ab}$ & 34.9 & $0.53 \mathrm{ab}$ \\
Gourov & 1275 & $32.4 \mathrm{~b}$ & 39.4 & $0.50 \mathrm{~b}$ \\
\hline LSD $(0.05)$ & $\mathrm{ns}$ & 4.6 & $\mathrm{~ns}$ & 0.08 \\
\hline $\mathrm{CV}(\%)$ & 11.93 & 9.38 & 8.89 & 9.16 \\
\hline
\end{tabular}


difference in respect of root weight and root-shoot ratio of wheat but the shoot weight was the highest in Kanchan followed by Protiva and Gourab. The root weight was the highest (1533 mg) in $\mathrm{T}_{7}$, which was statistically similar to $\mathrm{T}_{4}$, and $\mathrm{T}_{5}$ (Table $1 \mathrm{~b}$ ). Similarly the shoot weight at anthesis was the highest under $T_{7}$, which was statistically similar to $T_{4}$ and $\mathrm{T}_{5}$. But the root-shoot ratio was the highest $\left(40.8 \mathrm{mg} \mathrm{g}^{-1}\right)$ under $\mathrm{T}_{3}$ that was similar to $\mathrm{T}_{2}$. The result indicates that when all $\mathrm{N}$ fertilizer is applied at a time at $\mathrm{CRI}$ or 1st node stage $\left(\mathrm{T}_{3}\right.$ or $\left.\mathrm{T}_{2}\right)$ rather than splitting, caused decrease in root weight and in shoot weight but the reduction in shoot weight was more compare to root weight resulting higher value of root-shoot ratio compared with others. $N$ deficiency at earlier growth stages of the plant may lead to the higher value of root-shoot ratio in $\mathrm{T}_{3}$ and $\mathrm{T}_{2}$. Rahman et al. (2000b) also reported higher value of root-shoot ratio under $\mathrm{N}$ deficiency in wheat. Root length density at the active root zone $(0-15 \mathrm{~cm})$ was the highest $\left(0.72 \mathrm{~mm} \mathrm{~cm}^{-3}\right)$ under $\mathrm{T}_{7}$ that was significantly higher than all other treatments. Thus the application of $\mathrm{N}$ fertilizer in three equal split as basal fertilizer, at CRI and 1st node stage might brings significant positive effect on RLD of wheat. On the contrary RLD of wheat was the least under $T_{3}$, which might be due to $\mathrm{N}$ deficiency at the earlier stages of the plant.

\section{N uptake and NUE}

Nitrogen content in grain and straw and $\mathrm{N}$ uptake by the straw of all 3 genotypes of wheat was statistically similar but total $\mathrm{N}$ uptake and $\mathrm{N}$ uptake by the grain was different among the genotypes (Table 2a). Grain $N$ uptake and total $N$ uptake in Kanchan were the highest ( 61.9 and $91.7 \mathrm{~kg} \mathrm{ha}^{-1}$ ) followed by Protiva and Gourab. Physiological NUE, expressed as the ratio of grain yield to the total $\mathrm{N}$ uptake for one plant, was statistically similar among the wheat genotypes. But the agronomic NUE estimated as grain yield per $\mathrm{kg} \mathrm{N}$ applied was the highest (28.7) in Kanchan followed by Protiva and Gourab. The higher yield of Kanchan was caused solely by the greater value of $\mathrm{N}$ uptake and NUE of that genotype, as $\mathrm{N}$ content in grain and straw was similar among the genotypes. Grain $\mathrm{N}$

Table 1b. Root-shoot ratio and root length density at the active growing zone $(0-15 \mathrm{~cm})$ of wheat as influenced by different nitrogen management treatment under surface seeding condition in $2000-2001$

\begin{tabular}{|c|c|c|c|c|c|c|c|}
\hline \multicolumn{4}{|c|}{ Nitrogen management } & \multirow{2}{*}{$\begin{array}{c}\text { Root weight } \\
\mathrm{mg}\end{array}$} & \multirow{2}{*}{$\begin{array}{c}\text { Shoo wt. } \\
\text { g }\end{array}$} & \multirow{2}{*}{$\begin{array}{c}\text { Root:Shoot } \\
\mathrm{mg} \mathrm{g}^{-1}\end{array}$} & \multirow{2}{*}{$\begin{array}{c}\text { RLD } \\
\mathrm{cm} \mathrm{cm}^{-3}\end{array}$} \\
\hline & $\begin{array}{c}\text { Basal } \\
\text { fertilizer }\end{array}$ & $\begin{array}{c}\text { CRI } \\
\text { stage }\end{array}$ & $\begin{array}{l}1^{\text {st }} \text { node } \\
\text { stage }\end{array}$ & & & & \\
\hline $\mathrm{T}_{1}$ & $2 / 3$ & $1 / 3$ & 0 & $1,201 \mathrm{bc}$ & $34.1 \mathrm{bc}$ & $35.2 \mathrm{bc}$ & $0.56 \mathrm{~b}$ \\
\hline $\mathrm{T}_{2}$ & 0 & 1 & 0 & $1,143 \mathrm{c}$ & $31.0 \mathrm{cb}$ & $39.9 \mathrm{ab}$ & $0.43 \mathrm{c}$ \\
\hline $\mathrm{T}_{3}$ & 0 & 0 & 1 & $963 d$ & $23.6 \mathrm{~d}$ & $40.8 \mathrm{a}$ & $0.32 \mathrm{~d}$ \\
\hline $\mathrm{T}_{4}$ & $1 / 2$ & $1 / 2$ & 0 & $1,444 \mathrm{a}$ & $41.1 \mathrm{a}$ & $35.1 \mathrm{ac}$ & $0.61 \mathrm{~b}$ \\
\hline $\mathrm{T}_{5}$ & $1 / 2$ & 0 & $1 / 2$ & $1,341 \mathrm{ab}$ & $39.3 \mathrm{a}$ & $34.1 \mathrm{c}$ & $0.60 \mathrm{~b}$ \\
\hline $\mathrm{T}_{6}$ & 0 & $1 / 2$ & $1 / 2$ & $1,326 \mathrm{~b}$ & $36.9 \mathrm{~b}$ & $35.9 \mathrm{~b}$ & $0.58 \mathrm{~b}$ \\
\hline $\mathrm{T}_{7}$ & $1 / 3$ & $1 / 3$ & $1 / 3$ & $1,533 \mathrm{a}$ & $42.8 \mathrm{a}$ & $35.8 \mathrm{bc}$ & $0.72 \mathrm{a}$ \\
\hline LSD & & & & 193 & 5.2 & 4.5 & 0.1 \\
\hline $\mathrm{CV}(\%)$ & & & & 11.93 & 9.38 & 8.89 & 9.16 \\
\hline
\end{tabular}


Table 2a. $\mathrm{N}$ uptake and $\mathrm{N}$ use efficiency of wheat genotypes under surface seeding condition in $2000-2001$

\begin{tabular}{lccccccc}
\hline Genotype & $\begin{array}{c}\text { N content } \\
\text { G }\end{array}$ & \multicolumn{3}{c}{$\begin{array}{c}\text { N Uptake } \\
\text { kg ha }\end{array}$} & \multicolumn{3}{c}{ NUE } \\
\hline & Grain & Straw & Grain & Straw & Total & Physiological & Agronomic \\
\hline Kanchan & 1.81 & 0.49 & $61.9 \mathrm{a}$ & 29.8 & $91.7 \mathrm{a}$ & 37.5 & $28.7 \mathrm{a}$ \\
Protiva & 1.78 & 0.47 & $53.8 \mathrm{~b}$ & 26.3 & $80.1 \mathrm{~b}$ & 38.0 & $25.3 \mathrm{~b}$ \\
Gourov & 1.77 & 0.48 & $54.6 \mathrm{~b}$ & 25.7 & $80.3 \mathrm{~b}$ & 37.8 & $25.1 \mathrm{~b}$ \\
\hline LSD(0.05) & $\mathrm{ns}$ & $\mathrm{ns}$ & 7.1 & $\mathrm{~ns}$ & 10.1 & $\mathrm{~ns}$ & 3.2 \\
\hline CV(\%) & 6.71 & 9.3 & 8.38 & 9.24 & 7.85 & 6.8 & 6.15 \\
\hline
\end{tabular}

Table 2b. $\mathrm{N}$ uptake and $\mathrm{N}$ use efficiency of wheat as influenced by different nitrogen management practice in surface seeding condition in 2000-2001

\begin{tabular}{|c|c|c|c|c|c|c|c|c|c|c|}
\hline \multicolumn{3}{|c|}{$\begin{array}{l}\text { Nitrigen } \\
\text { management }\end{array}$} & & \multicolumn{2}{|c|}{$\begin{array}{c}\text { N Content } \\
\%\end{array}$} & \multicolumn{2}{|c|}{$\begin{array}{l}\text { N Uptake } \\
\mathrm{kg} \mathrm{ha}^{-1}\end{array}$} & \multicolumn{3}{|c|}{ NUE } \\
\hline & & & & Grain & straw & grain & Straw & Total & Physiological & Agronomic \\
\hline & Basal fertilizer & $\begin{array}{c}\text { CRI } \\
\text { stage }\end{array}$ & $\begin{array}{l}1^{\text {stnode }} \\
\text { stage }\end{array}$ & & & & & & & \\
\hline $\mathrm{T}_{1}$ & $2 / 3$ & $1 / 3$ & 0 & $1.73 \mathrm{~b}$ & $0.41 \mathrm{~b}$ & $49.3 \mathrm{c}$ & $25.2 \mathrm{bc}$ & $74.5 \mathrm{~cd}$ & $38.3 \mathrm{a}$ & $23.7 \mathrm{c}$ \\
\hline $\mathrm{T}_{2}$ & 0 & 1 & 0 & $1.77 \mathrm{~b}$ & $0.39 \mathrm{~b}$ & $49.7 \mathrm{c}$ & $22.4 \mathrm{c}$ & $72.1 \mathrm{~d}$ & $38.8 \mathrm{a}$ & $23.3 \mathrm{c}$ \\
\hline $\mathrm{T}_{3}$ & 0 & 0 & 1 & $1.75 \mathrm{~b}$ & $0.64 \mathrm{a}$ & $47.1 \mathrm{c}$ & $33.4 \mathrm{a}$ & $80.5 \mathrm{c}$ & $33.4 \mathrm{~b}$ & $22.4 \mathrm{c}$ \\
\hline $\mathrm{T}_{4}$ & $1 / 2$ & $1 / 2$ & 0 & $1.75 \mathrm{~b}$ & $0.44 \mathrm{~b}$ & $52.1 \mathrm{c}$ & $29.8 \mathrm{~b}$ & $81.9 \mathrm{c}$ & $36.6 \mathrm{a}$ & $24.8 b c$ \\
\hline $\mathrm{T}_{5}$ & $1 / 2$ & 0 & $1 / 2$ & $1.81 \mathrm{ab}$ & $0.47 \mathrm{~b}$ & $60.3 \mathrm{~b}$ & $28.8 \mathrm{~b}$ & $89.1 \mathrm{bc}$ & $37.4 \mathrm{a}$ & $27.7 \mathrm{~b}$ \\
\hline $\mathrm{T}_{6}$ & 0 & $1 / 2$ & $1 / 2$ & $1.84 \mathrm{ab}$ & $0.44 \mathrm{~b}$ & $64.6 \mathrm{~b}$ & $27.8 \mathrm{~b}$ & $92.4 \mathrm{~b}$ & $38.0 \mathrm{a}$ & $29.2 \mathrm{~b}$ \\
\hline $\mathrm{T}_{7}$ & $1 / 3$ & $1 / 3$ & $1 / 3$ & $2.09 \mathrm{a}$ & $0.51 \mathrm{ab}$ & $83.3 \mathrm{a}$ & $30.1 \mathrm{~b}$ & $113.4 \mathrm{a}$ & $35.1 \mathrm{ab}$ & $33.1 \mathrm{a}$ \\
\hline LSD & & & & 0.19 & 0.14 & 7.8 & 3.3 & 9.8 & 3.2 & 3 \\
\hline CV(\%) & & & & 6.71 & 9.3 & 8.38 & 9.24 & 7.85 & 6.85 & 6.15 \\
\hline
\end{tabular}

content was the highest (2.09\%) in $\mathrm{T}_{7}$ that was statistically identical to $\mathrm{T}_{6}$ and $\mathrm{T}_{5}$ (Table $2 \mathrm{~b}$ ). Thus the second top dressing of $\mathrm{N}$ fertilizer at 1st node stage may have significant effect in increasing grain $\mathrm{N}$ content in wheat. Ortiz-Monaterio et al. (1994) also reported that delay application of $\mathrm{N}$ up to first node resulted in a dramatic increase in $\mathrm{N}$ content in flour. When all $\mathrm{N}$ was applied at a time at 1 st node stage $\left(\mathrm{T}_{3}\right)$ the straw $\mathrm{N}$ content was the highest $(0.64 \%)$ but it did not contributed to achieve higher $\mathrm{N}$ content in grain. The grain $\mathrm{N}$ uptake and the total $\mathrm{N}$ uptake by the plant was the highest $\left(83.3\right.$ and $113.4 \mathrm{~kg} \mathrm{ha}^{-1}$ ) under $\mathrm{T}_{7}$ indicated that application of $\mathrm{N}$ fertilizer in three split had significant positive effect on $\mathrm{N}$ uptake by the plant. Physiological NUE of wheat was statistically similar among all $\mathrm{N}$ managements except in $\mathrm{T}_{3}$ that had the least (33.4) physiological NUE compare with others. The agronomic NUE was the highest (33.1) under $\mathrm{T}_{7}$ followed by $\mathrm{T}_{6}$ and $\mathrm{T}_{5}$. Therefore the second top dressing of $\mathrm{N}$ fertilizer at first node stage of wheat 
might have effect in increasing $\mathrm{N}$ uptake, $\mathrm{N}$ content in grain and NUE in surface seeding wheat. Ortiz-Monaterio et al. (1994) also reported that NUE was the highest when one third of $\mathrm{N}$ was applied at planting and two-third was applied in two split before first node.

\section{Yield attribute}

The grain yield and yield contributing characters of wheat were significantly influenced by different $\mathrm{N}$ management practices in 1999-2001. It was also found that varietal difference in yield and in yield component of wheat under surface seeding over the years is large (Table 3a). Spikes $\mathrm{m}^{-2}$ was statistically similar among the genotypes in 1999-2000, but in the next year it became significantly higher in Kanchan followed by Protiva and Gourab. The number of grains spike ${ }^{-1}$ was the highest (29.6 in 1999-2000 and 33.8 in 2000-01) in Kanchan followed by Protiva and Gourab. Similarly Kanchan gave the highest yield ( $3.16 \mathrm{t} \mathrm{ha} \mathrm{h}^{-1}$ in $1999-00$ and $3.44 \mathrm{t} \mathrm{ha}^{-1}$ in 2000-01) followed by Protiva and Gourab. However, the grain yield of Protiva and Gourab was statistically similar for both the years.

Due to $\mathrm{N}$ management, $\mathrm{T}_{7}$ was found the best treatment in surface seeding condition that produced significantly high number of spikes $\mathrm{m}^{-2}$, grains spike ${ }^{-1}$ and grain yield compare to others (Table $3 \mathrm{~b}$ ). In general, the treatments with no splitting of $\mathrm{N}$ fertilizer $\left(\mathrm{T}_{2}\right.$ and $\mathrm{T}_{3}$ ) yield poorly compare to others in these years. The lowest yield was found under $\mathrm{T}_{3}$ where all $\mathrm{N}$ fertilizer was applied at 1st node stage of wheat. The highest yield of $3.23 \mathrm{t} \mathrm{ha}^{-1}$ in 1999-2000 and 3.98 $\mathrm{t} \mathrm{ha}^{-1}$ in 2000-01 was obtained from $\mathrm{T}_{7}$. The higher grain yield came from higher yield of spikes $\mathrm{m}^{-2}$ and grains spike ${ }^{-1}$. Our results look like the report of Ortiz-Monasterio et al. (1994) that the split application of nitrogen until the first node formation resulted in increased yield in wheat in evaluating several nitrogen application strategies in northwestern Mexico. Aslam et al. (1993) also indicated that split application of $\mathrm{N}$ fertilizer up to 1st node stage is better than basic fertilizer application in surface seeded wheat.

From the two years experiments it may concluded that the surface seeding Kanchan may be more advantageous rather than Protiva and Gourab and that three splits of $\mathrm{N}$ fertilizer as 1/3 basic fertilizer during seeding, 1/3 at CRI (20 DAS) and 1/3 at 1st node stage (35 DAS) is useful to maximize the efficiency of applied $\mathrm{N}$ fertilizer and higher yield in surface seeded wheat.

Table 3a. Yield attributes of wheat genotypes in surface seeding condition in two consecutive years of 1999-2000 and 2000-2001

\begin{tabular}{|c|c|c|c|c|c|c|}
\hline \multirow[t]{2}{*}{ Genotype } & \multicolumn{3}{|c|}{$1999-2000$} & \multicolumn{3}{|c|}{$2000-2001$} \\
\hline & $\begin{array}{c}\text { Spikes } \\
\mathrm{m}^{-2}\end{array}$ & $\begin{array}{l}\text { Grains } \\
\text { spike }^{-1}\end{array}$ & $\begin{array}{l}\text { Yield } \\
\text { tha }^{-1}\end{array}$ & $\begin{array}{c}\text { Spiles } \\
\mathrm{m}^{-2}\end{array}$ & $\begin{array}{l}\text { Grains } \\
\text { spike }^{-1}\end{array}$ & $\begin{array}{l}\text { Yield } \\
\text { tha }^{-1}\end{array}$ \\
\hline Kanchan & 335.7 & $29.6 \mathrm{a}$ & $3.16 \mathrm{a}$ & $331 \mathrm{a}$ & $33.8 \mathrm{a}$ & $3.44 \mathrm{a}$ \\
\hline Protiva & 314.7 & $26.1 \mathrm{~b}$ & $2.69 \mathrm{~b}$ & $319 a b$ & $29.6 \mathrm{~b}$ & $3.04 \mathrm{~b}$ \\
\hline Gourov & 319.4 & $25.6 \mathrm{~b}$ & $2.52 \mathrm{~b}$ & $288 \mathrm{~b}$ & $29.2 \mathrm{~b}$ & $3.01 \mathrm{~b}$ \\
\hline $\operatorname{LSD}(0.05)$ & ns & 3.3 & 0.28 & 29.8 & 4.1 & 0.36 \\
\hline CV $(\%)$ & 10.23 & 9.87 & 10.23 & 9.54 & 9.66 & 8.45 \\
\hline
\end{tabular}


Table 3b. Yield attributes of wheat as influenced by nitrogen management practice in surface seeding condition in two consecutive year of 1999-2000 and 2000-2001

\begin{tabular}{|c|c|c|c|c|c|c|c|c|c|}
\hline & \multicolumn{3}{|c|}{$1999-2000$} & \multicolumn{3}{|c|}{$2000-2001$} \\
\hline \multicolumn{4}{|c|}{ Nitrogen Management } & $\begin{array}{c}\text { Spikes } \\
\mathrm{m}^{-2}\end{array}$ & $\begin{array}{l}\text { Grains } \\
\text { spike }^{-1}\end{array}$ & $\begin{array}{l}\text { Yield } \\
\text { tha }^{-1}\end{array}$ & $\begin{array}{l}\text { Spiles } \\
\mathrm{m}^{-2}\end{array}$ & $\begin{array}{l}\text { Grains } \\
\text { spike }^{11}\end{array}$ & $\begin{array}{l}\text { Yield } \\
\text { tha }^{-1}\end{array}$ \\
\hline & $\begin{array}{c}\text { Basal } \\
\text { fertilizer }\end{array}$ & $\begin{array}{l}\text { CRI } \\
\text { stage }\end{array}$ & $\begin{array}{l}1^{\text {st node }} \\
\text { stage }\end{array}$ & & & & & & \\
\hline $\mathrm{T}_{1}$ & $2 / 3$ & $1 / 3$ & 0 & $343.8 \mathrm{~b}$ & $27.6 \mathrm{~b}$ & $2.84 \mathrm{bc}$ & $295 \mathrm{~b}$ & $29.2 \mathrm{bc}$ & $2.85 \mathrm{~cd}$ \\
\hline $\mathrm{T}_{2}$ & 0 & 1 & 0 & $351.3 \mathrm{~b}$ & $24.2 \mathrm{c}$ & $2.62 \mathrm{c}$ & $299 \mathrm{~b}$ & $28.6 \mathrm{c}$ & $2.80 \mathrm{~cd}$ \\
\hline $\mathrm{T}_{3}$ & 0 & 0 & 1 & $289.0 \mathrm{~d}$ & $21.7 \mathrm{c}$ & $2.15 \mathrm{~d}$ & $309 \mathrm{~b}$ & $23.2 \mathrm{~d}$ & $2.69 \mathrm{~d}$ \\
\hline $\mathrm{T}_{4}$ & $1 / 2$ & $1 / 2$ & 0 & $328.4 \mathrm{bc}$ & $27.8 \mathrm{~b}$ & $2.83 \mathrm{bc}$ & $314 \mathrm{~b}$ & $28.9 \mathrm{c}$ & $2.97 \mathrm{c}$ \\
\hline $\mathrm{T}_{5}$ & $1 / 2$ & 0 & $1 / 2$ & $350.0 \mathrm{~b}$ & $27.4 \mathrm{~b}$ & $2.98 \mathrm{ab}$ & $311 b$ & $30.1 \mathrm{bc}$ & $3.33 \mathrm{~b}$ \\
\hline $\mathrm{T}_{6}$ & 0 & $1 / 2$ & $1 / 2$ & $319.1 \mathrm{~cd}$ & $28.4 \mathrm{~b}$ & $2.59 \mathrm{c}$ & $321 \mathrm{ab}$ & $31.1 \mathrm{~b}$ & $3.51 \mathrm{~b}$ \\
\hline $\mathrm{T}_{7}$ & $1 / 3$ & $1 / 3$ & $1 / 3$ & $371.3 \mathrm{a}$ & $33.5 \mathrm{a}$ & $3.23 \mathrm{a}$ & 337 a & $37.2 \mathrm{a}$ & $3.98 \mathrm{a}$ \\
\hline LSD & & & & 29.5 & 2.5 & 0.28 & 26 & 2.9 & 0.26 \\
\hline CV(\% & & & & 10.23 & 9.87 & 10.23 & 9.54 & 9.66 & 8.45 \\
\hline
\end{tabular}

\section{REFERENCES}

Ahmed, S. M. and C. A. Meisner 1996 In: Wheat Research and Development in Bangladesh. Bangladesh Australia Wheat Improvement Project and CIMMYT Bangladesh. Published by Aus AID and CIMMYTBangladesh Uttra, Dkaka

Aslam, M., N. I. Hashmi, A. Majid and P. R. Hobbs 1993 Improving wheat yield in the rice-wheat cropping system of the Panjab through fertilizer manangement. Pakistan J. Agril. Res., 14: 1-7

Fisher, R. A., G. N. Howe and Z. Ibrahim 1993 Irrigated spring wheat and timing and amount of nitrogen fertilizer. I. Grain yield and protein content. Field Crops Res, , 33: 37-56

Hobbs, P. R., G. S. Giri and P. Grace 1998 Reduced and zero tillage options for the establishment of wheat after rice in the South Asia. RWCIGP Paper No-2: Mexico, D. F.: RWCIGP and CIMMYT

Khan, R. A., S. S. Tomar, N. S. Yadar, R. B. Sharma, P. S. Kushwah and M. P. Jain. 1990 Response of wheat to irrigation and nitrogen. Ind. Jour. Agron., 35: 414-416

Malik, C. V. S. 1981 Response of wheat varieties to different level of nitrogen. Ind. Jour. Agron., 26: 93-96

Newman, E. I 1966 A method of estimating the total length of root in a sample. Jour. Appl. Ecol., 3:139-145

Ortiz-Monasterio, J. I., K. D. Sayre, J. Pena and R. A. Fisher 1994 Improving the nitrogen use efficiency of irrigated spring wheat in the Yaqui Vally of Merxico. Trans. 15th World Congr. Soil Sci., 5b: $348-349$

Prasad, U. K., R. D. Pandey, T. N. Prasad, and A. K. Jah 1987 Effect of irrigation and nitrogen on wheat. Ind. Jour. Agron., 32: 310-313

Rahman, M. A., A. J. M. S. Karim, A. R. M. Solaiman and K. Egashira 2000a Effect of irrigation and nitrogen fertilization on $\mathrm{N}$ uptake and efficiency of wheat on a Clay Terrace Soil of Bangladesh. J. Fac. Agr. Kyushu Univ., 45: 309-316

Rahman, M. A., A. J. M. S. Karim, M. M. Hoque and K. Egashira 2000b Effect of irrigation and nitrogen fertilization on root growth and root characteristics of wheat on a Clay Terrace Soil of Bangladesh. $J$. Fac. Agr. Kyushu Univ., 45: 301-308

Razzaque, M. A., A. B. S. Hossain and M. A Hossain 1980 Effect of nitrogen rates and their time of application on HYV wheat. Bangladesh Jour. Agric. Res., V: 33-40

Tennant, D 1975 A test of a modified line intersect method of estimating root length. Jour. Appl. Ecol., 63: $995-1001$ 